\title{
Training of students' special endurance in ping pong sport circles
}

\author{
Grinko V.M. ${ }^{1}$, Kudelko V.E. ${ }^{2}$, Hlotov Y.O. ${ }^{2}$ \\ ${ }^{1}$ Kharkiv State Academy of Physical Culture \\ ${ }^{2}$ Kharkiv Institute of Finance Kyiv National Trade - Economic University
}

\begin{abstract}
Purpose:

to test experimentally influence of aerobic trainings (cross country training and basic aerobic) on students' special endurance in sport oriented groups (sport circles, ping pong).

Material: 106 first year students ( $n=53$ - control group and $n=53$ - experimental) participated in experiment. For determination of temporal series' trends R-S analysis was used. Prognostication of mistakes' quantity per one set was fulfilled with the help of exponential smoothing method.

Results: $\quad$ it was shown that exponential smoothing method permits to prognosticate by one set ahead with rather high accuracy. As initial predictor we found mean quantity of mistakes in all sets. It permits to average all internal and external factors, which influence on the next predicting indicators. Such approach increases confidence of mistakes' calculation in prognostication. Criteria of prognostication methodic for possible indicators' values were also determined.

Conclusions: the recommended time distribution in program is as follows: ping pong $-75 \%$; cross country training and basic aerobic $-25 \%$.

Keywords: $\quad$ ping pong, aerobic, special endurance, trends, fractal analysis.
\end{abstract}

\section{Introduction}

The problem of students' physical education improvement has bee being an objects of specialists' attention already for many years [3, 21, 23]. Analysis of literature sources shows that physical training level, psychic and moral potentials of most students is still rather low [11, 22]. It points at worsening of young generation's physical, psychic and mental development $[7,24]$, progressing of motor functioning deficit [10]. All these witness about demand in seeking new ways for improvement of students' physical, psychic and moral condition $[27,28]$. Besides, it is noted that it is important to train physical qualities [4]. The supplied facts witness that students understand importance of endurance influence and its significance in preparation for labor activity. Students also understand that just this quality is the worst in most of them $[4,10]$. The authors recommend approaches to correcting academic program for sport oriented groups (sport circles' training). Improvement of students' physical fitness has been being regarded by many scientists recent years [3, 5, 9]. Their works are devoted to physical endurance. But there is deficit of works on special endurance training in sport oriented groups (sport circles' ping pong trainings). Besides, there are a few researches on special endurance training by cross country race means and with the help of basic aerobic in sport circles' trainings [5, 9]. An addition to solution of the mentioned problems could be study of dynamic processes with the help of fractal geometry $[17,20,25,27]$. The authors note that there is no universal model, which could be used for dynamic processes' description.

The purpose of the research is to determine influence of aerobic trainings (cross country training and basic aerobic) on students' special endurance in sport oriented groups (sport circles, ping pong).

\footnotetext{
c) Grinko V.M., Kudelko V.E., Hlotov Y.O., 2017

doi:10.15561/20755279.2017.0201
}

\section{Material and methods}

Participants: 106 first year students ( $\mathrm{n}=53$ control group and $n=53$ - experimental) participated in experiment. All participants gave written consent for participation in this experiment.

Organization of the research: the experiment was being fulfilled during academic year - from October 2015 to June 2016. Control group students were trained by program of higher educational establishments for sport oriented groups (sport circles' trainings, ping pong). Experimental group students were trained by the worked out by us program. This program combines special sport trainings (ping pong $-75 \%$ ) and aerobic trainings (cross country training and basic aerobic $-25 \%$ ). As the base we took higher educational program for sport oriented groups (sport circles' trainings, ping pong). Additionally, every forth training of this program included aerobic loads (cross country training and basic aerobic). Up to the middle of December experimental group students trained cross country race in the fresh air. Then the trainings were conducted in gym. With it every forth training included basic aerobic elements. At the end of March trainings again started in the fresh air, with cross country race at every forth class. At the beginning and at the end of experiment we conducted ping pong competitions. It permitted to test students' endurance [14]. Every pair of students played five sets. The quantity of made mistakes was registered in each set.

Statistical analysis: statistical and comparative analyses of the received data were fulfilled for testing of special endurance at the beginning and at the end of experiment. The method of pair regression was used for this purpose [8]. Besides, Fisher's F criterion and Student's $\mathrm{t}$ criterion were used. Analysis of pair regression linear equation was fulfilled also $[15,17,26]$. We calculated linear coefficients of pair correlation, determination and approximation mean error [2, 6, 25]. Besides, we assessed statistical significance of regression and correlation 
parameters $[12,13,29]$; found excessive regression and calculated confidence intervals [16].

\section{Results}

For prognostication it is necessary to analyze temporal series and find if the studied system is persistent or non persistent; if its behavior is caused by determinate non linear law or it is completely occasional. In work [26] it was mentioned that any assessment method of change in time prognostication requires consideration of their temporal series' fractal attributes. Different fractal structures in different systems cause fractal behavior of such systems' indicators. For prognostication of such systems' behavior (determination of changes' tendencies) Hurst's method is used [13]. In works [16, 16] algorithm of Hurst's indicator is given, which characterizes such attributes. After determination of Hurst's indicator methodic of possible series' values prognostication is chosen depending on its persistence. The following formula ( $\mathrm{T}-$ time) is in the base of this method:

$$
\mathrm{R}=\mathrm{T}^{1 / 2} \text {, (1). }
$$

Hurst found more general equation (1):

$$
(\mathrm{R} / \mathrm{S})_{\mathrm{n}}=\mathrm{c}^{*} \mathrm{n}^{\mathrm{H}},(2)
$$

Where $\mathrm{R}$ - range of deviations, $\mathrm{S}$ - standard deviation, c - constant, $\mathrm{n}$ - quantity of measurements, $\mathrm{H}$ - Hurst's indicator (from 0 to 1 ). If to take logarithm from expression (2) we shall receive the following:

$$
\operatorname{Ln}(\mathrm{R} / \mathrm{S})_{\mathrm{n}}=\operatorname{Ln}(\mathrm{c})+\mathrm{H}^{*} \operatorname{Ln}(\mathrm{n}),(3) \text {. }
$$

It permits to find Hurst's indicator $(\mathrm{H})$ through building dependence $\operatorname{Ln}(\mathrm{R} / \mathrm{S})_{\mathrm{n}}$ on $\mathrm{Ln}(\mathrm{n})$ and determine inclination of trend line with the help of simple regression.

Algorithm of Hurst's indicator determination (fractal method, based on R/S analysis or method of standardized range) is as follows: temporal series of length $M$ is transformed in temporal series of length $=\mathrm{M}-1$ by logarithmic relations $\mathrm{N}_{\mathrm{t}}=\mathrm{Ln}\left(\mathrm{M}_{\mathrm{t}+1} / \mathrm{M}_{\mathrm{t}}\right), \mathrm{t}=1,2,3 \ldots . \mathrm{M}-1$. Temporal series $\mathrm{N}_{\mathrm{t}}$ is divided into a number of adjoining sub-periods of length $n=2,3 \ldots N$. Deviation for every sub-period from mean value (accumulated deviations) is calculated in the following way:

$$
X_{u, n}=\sum_{u=1}^{t}\left(e_{u}-M\right),(4)
$$

Where $\mathrm{n}$ - length of sub-period, which changes from 2 to the length of temporal series t; $\mathrm{M}$ - mean value of elements in sub-period; e - specific element of subperiod; u - number of sub-period's element. On every iteration we calculate deviations' range $\mathrm{X}$ u,n:

$$
R=\operatorname{Max}\left(X_{u, n}\right)-\operatorname{Min}\left(X_{u, n}\right),(5) \text {. }
$$

Standardizing of range we find by division on standard deviation $\mathrm{S}$, which is found by $\mathrm{n}$ values of sub-period. Then we find logarithm R/S and $n$ and on the base of the received data build graph of linear regression. By graph of $\operatorname{Ln}(\mathrm{R} / \mathrm{S})$ on $\mathrm{Ln}(\mathrm{n})$ function, we find inclination with method of linear approximation. Tangent of linear graph inclination angle is exactly Hurst's indicator. Hurst's indicator is connected with fractal dimension span of D curve by relation:

$$
\mathrm{D}=2-\mathrm{H},(6)
$$

Where $\mathrm{D}$ is fractal dimension span of the curve, indicator $\mathrm{H}$ can be from 0 to 1 . For system's analyzing Hurst's indicator can take the following values:

1. $0 \leq \mathrm{H}<0.5$ or $1.5<\mathrm{D} \leq 2$ temporal series is not persistent ("pink noise"): one can observe economic system's bent to constant change of tendency (increase is replaced by drops and vice versa). The closer its value is to zero the more changeable is series. Such systems are often called "return to average".

2. $\mathrm{H}=0.5$ or $\mathrm{D}=1.5$ - numerical series is absolutely occasional ("white noise"): there is full absence of long statistic dependence (occasional behavior of economic indicator);

3. $0.5<\mathrm{H} \leq 1$ or $1<\mathrm{D}<1.5$ - persistent temporal series ("black noise"), in which a trend is observed, as well as tendency to increasing or falling down of indicator (both in the past and in the future), The higher indicator is the more often indicator' rising is followed by rising (falling down - by falling down).

Distinction of Hurst's indicator from 0.5 is a particular reflection of processes' fractal attributes, which cause temporal series. Application of persistence (or non persistence) permits to comparatively easy and reliably prognosticate future development of the studied process on the base of his history data. In works [2, 26] it was found that these attributes are valid even in case of relatively short temporal series. That is why we regard application of R/S indicator for analysis of mean quantity of mistakes in ping pong, made by experimental group students in October (see table 1). According to algorithm of Hurst's indicator determination we construct a table for finding this indicator's parameters. By the data of $\operatorname{Ln}(\mathrm{R} / \mathrm{S})$ and $\operatorname{Ln}(n)$ temporal series $\mathbf{Y}$ (see table 1) we find equation of linear regression: $\mathrm{Y}=0.1253 \mathrm{x}+0.2486, \mathrm{R} 2=0.8751$. Thus, standardized rage $\mathrm{R} / \mathrm{S}$ - is increasing value and can be described by linear regression equation in logarithmic form:

$$
\operatorname{Ln}(\mathrm{R} / \mathrm{S})=0.1253 * \operatorname{Ln}(\mathrm{n})+0.2486 \text {. }
$$

From this equation we find that $\mathrm{H}=0.1253$ and $\mathrm{D}=$ $2-0.1253=1.8747$.

It means that this numerical series can be prognosticated.

In similar way we find equation of standardized range for temporal series of experimental groups (May) and control group (October and May). In table 2 there are given experimental group May data.

As per table 2 data we find the equation:

$$
\begin{gathered}
\operatorname{Ln}(\mathrm{R} / \mathrm{S})=0.2314 * \operatorname{Ln}(\mathrm{n})+0.1526, \mathrm{R} 2=0.9273 . \mathrm{H}= \\
0.2314 \text { and } \mathrm{D}=2-0.2314=1.5561 .
\end{gathered}
$$

Control group ping pong parameters in October are given in table 3.

By table 3 data we find the equation:

$\mathrm{Ln}(\mathrm{R} / \mathrm{S})=0.2138 * \mathrm{Ln}(\mathrm{n})+0.1653, \mathrm{R} 2=0.9348 . \mathrm{H}=$ 0.2138 and $\mathrm{D}=2-0.2138=1.7862$. 
Pes

Table 1. Parameters for Hurst's indicator determination (experimental group ping pong in October) 2015

\begin{tabular}{|c|c|c|c|c|c|}
\hline \multirow{2}{*}{$\begin{array}{l}\text { Set № } \\
\text { (X) }\end{array}$} & \multicolumn{5}{|c|}{ Parameters for Hurts's indicator determination (experimental group ping pong in October) 2015} \\
\hline & Quantity of mistakes (Y) & $\mathrm{Nt}=\operatorname{Ln}(\mathrm{Yi}+1 / \mathrm{Yi})$ & Deviation $f_{t}$ & mean value & \\
\hline 1 & 4.24 & & & & \\
\hline 2 & 5.00 & 0.165 & -0.00032 & 0.0230 & 0.0363 \\
\hline 3 & 5.90 & 0.166 & 0.00032 & 0.0236 & 0.0370 \\
\hline 4 & 6.49 & 0.095 & & -0.0466 & -0.0332 \\
\hline \multirow[t]{2}{*}{5} & 7.09 & 0.088 & & & -0.0401 \\
\hline & & \multicolumn{4}{|c|}{ Statistical indicators for R/S analysis } \\
\hline \multirow{9}{*}{\multicolumn{2}{|c|}{ Length of sub-period n }} & & 2 & 3 & 4 \\
\hline & & Mean value & 0.165 & 0.142 & 0.129 \\
\hline & & Max & 0.00032 & 0.02361 & 0.03698 \\
\hline & & Min & -0.00032 & -0.04659 & -0.04011 \\
\hline & & $\mathrm{R}=$ Max-Min & 0.00064 & 0.07020 & 0.07709 \\
\hline & & $\mathrm{S}$ & 0.0004524 & 0.040349023 & 0.04243004 \\
\hline & & $\mathrm{R} / \mathrm{S}$ & 1.4142136 & 1.739924633 & 1.1691152 \\
\hline & & $\operatorname{Ln}(R / S)$ & 0.347 & 0.554 & 0.597 \\
\hline & & $\operatorname{Ln}(n)$ & 0.7 & 1.1 & 1.4 \\
\hline
\end{tabular}

Table 2. Parameters for Hurst's indicator determination (experimental group ping pong in May) 2016

\begin{tabular}{|c|c|c|c|c|c|}
\hline \multirow{2}{*}{$\begin{array}{l}\text { Set № } \\
\text { (X) }\end{array}$} & \multicolumn{5}{|c|}{ Parameters for Hurts's indicator determination (experimental group ping pong in May) 2016} \\
\hline & \multirow[t]{2}{*}{ Quantity of mistakes (Y) } & \multirow[t]{2}{*}{$\mathrm{Nt}=\operatorname{Ln}(\mathrm{Yi}+1 / \mathrm{Yi})$} & \multicolumn{3}{|c|}{ Deviation from mean value } \\
\hline 1 & & & & & \\
\hline 2 & 4.45 & 0.102 & 0.01191 & 0.0262 & 0.0378 \\
\hline 3 & 4.81 & 0.078 & -0.01191 & 0.0024 & 0.0139 \\
\hline 4 & 5.04 & 0.047 & & -0.0287 & -0.0172 \\
\hline \multirow[t]{2}{*}{5} & 5.19 & 0.029 & & & -0.0345 \\
\hline & & \multicolumn{3}{|c|}{ Statistical indicators for $\mathrm{R} / \mathrm{S}$ analysis } & \\
\hline \multirow{9}{*}{\multicolumn{2}{|c|}{ Length of sub-period, $n$}} & & 2 & 3 & 4 \\
\hline & & Mean value & 0.090 & 0.075 & 0.064 \\
\hline & & Max & 0.01191 & 0.02625 & 0.03776 \\
\hline & & Min & -0.01191 & -0.02867 & -0.03454 \\
\hline & & $\mathrm{R}=$ Max-Min & 0.02383 & 0.05491 & 0.07229 \\
\hline & & $\mathrm{S}$ & 0.01685 & 0.027536 & 0.032180501 \\
\hline & & $\mathrm{R} / \mathrm{S}$ & 1.414214 & 1.994207 & 2.24653368 \\
\hline & & $\operatorname{Ln}(R / S)$ & 0.347 & 0.690 & 0.809 \\
\hline & & $\operatorname{Ln}(n)$ & 0.7 & 1.1 & 1.4 \\
\hline
\end{tabular}

Parameters of Hurst's indicator determination in control group May ping pong are given in table 4.

By the table 4 data we find equation:

$\operatorname{Ln}(\mathrm{R} / \mathrm{S})=0.2284 * \operatorname{Ln}(\mathrm{n})+0.1483, \quad \mathrm{R} 2=0.9504 . \mathrm{H}=$

0.2284 and $\mathrm{D}=2-0.2284=1.7716$.

For temporal series (see table 1-4) Hurst's indicator $0 \leq \mathrm{H}<0.5 ; 1.5<\mathrm{D} \leq 2$ means that temporal series are non persistent (indicators' bent to constant change of tendency).

Such type of numerical series is often called "return to average". That is why for prognostication exponential smoothing can be chosen. This method permits to choose as initial prognostication value mean quantity of mistakes in all sets. It means that it is possible to average all internal and external factors, influencing on the next prognostication indicators. It raises confidence of errors' calculation in prognostication. As coefficient of smoothing ( $\alpha=0.1-0.9$ ) we choose the value under which mean square difference between model and actual indicators would be minimal.

For exponential smoothing we take the following formula (7): 
Table 3. Parameters of Hurst's indicator determination in control group (ping pong in October) 2015

\begin{tabular}{|c|c|c|c|c|c|}
\hline \multirow{3}{*}{$\begin{array}{l}\text { Set № } \\
\text { (X) } \\
1\end{array}$} & \multicolumn{5}{|c|}{ Parameters of Hurst's indicator determination in control group (ping pong in October) 2015} \\
\hline & \multirow{2}{*}{$\begin{array}{l}\text { Quantity of mistakes (Y) } \\
4,25\end{array}$} & \multirow[t]{2}{*}{$\mathrm{Nt}=\operatorname{Ln}(\mathrm{Yi}+1 / \mathrm{Yi})$} & \multicolumn{3}{|c|}{ Deviation from mean value } \\
\hline & & & & & \\
\hline 2 & 5,11 & 0.184 & 0.02967 & 0.0468 & 0.0542 \\
\hline 3 & 5,79 & 0.125 & -0.02967 & -0.0126 & -0.0051 \\
\hline 4 & 6,42 & 0.103 & & -0.0342 & -0.0268 \\
\hline \multirow[t]{2}{*}{5} & 7,15 & 0.108 & & & -0.0224 \\
\hline & & \multicolumn{4}{|c|}{ Statistical indicators for $\mathrm{R} / \mathrm{S}$ analysis } \\
\hline \multirow{9}{*}{\multicolumn{2}{|c|}{ Length of sub-period, $n$}} & & 2 & 3 & 4 \\
\hline & & Mean value & 0.155 & 0.137 & 0.130 \\
\hline & & Max & 0.02967 & 0.04678 & 0.05423 \\
\hline & & Min & -0.02967 & -0.03421 & -0.02676 \\
\hline & & $\mathrm{R}=$ Max - Min & 0.05935 & 0.08099 & 0.08099 \\
\hline & & $S$ & 0.041965 & 0.041934 & 0.037342 \\
\hline & & $\mathrm{R} / \mathrm{S}$ & 1.414214 & 1.93147 & 2.169008 \\
\hline & & $\operatorname{Ln}(R / S)$ & 0.347 & 0.658 & 0.774 \\
\hline & & $\operatorname{Ln}(n)$ & 0.7 & 1.1 & 1.4 \\
\hline
\end{tabular}

Table 4. Parameters of Hurst's indicator determination in control group May ping pong, 2016

\begin{tabular}{|c|c|c|c|c|c|}
\hline \multirow{2}{*}{$\begin{array}{l}\text { Set № } \\
\text { (X) }\end{array}$} & \multicolumn{5}{|c|}{ Parameters of Hurst's indicator determination in control group May ping pong, 2016} \\
\hline & \multirow{2}{*}{$\frac{\text { Quantity of mistakes (Y) }}{3.94}$} & \multirow[t]{2}{*}{$N t=\operatorname{Ln}(Y i+1 / Y i)$} & \multicolumn{3}{|c|}{ Deviation from mean value } \\
\hline & & & & & \\
\hline 2 & 4.43 & 0.117 & 0.00413 & 0.0121 & 0.0210 \\
\hline 3 & 4.94 & 0.109 & -0.00413 & 0.0039 & 0.0127 \\
\hline 4 & 5.40 & 0.089 & & -0.0160 & -0.0072 \\
\hline \multirow[t]{2}{*}{5} & 5.79 & 0.070 & & & -0.0265 \\
\hline & & \multicolumn{4}{|c|}{ Statistical indicators for $\mathrm{R} / \mathrm{S}$ analysis } \\
\hline \multirow{9}{*}{\multicolumn{2}{|c|}{ Length of sub-period, $n$}} & & 2 & 3 & 4 \\
\hline & & Mean values & 0.113 & 0.105 & 0.096 \\
\hline & & Max & 0.00413 & 0.01215 & 0.02098 \\
\hline & & Min & -0.00413 & -0.01604 & -0.02650 \\
\hline & & $\mathrm{R}=$ Max-Min & 0.00825 & 0.02819 & 0.04749 \\
\hline & & $\mathrm{S}$ & 0.005836 & 0.01449 & 0.021265 \\
\hline & & $\mathrm{R} / \mathrm{S}$ & 1.414214 & 1.945112 & 2.233044 \\
\hline & & $\operatorname{Ln}(R / S)$ & 0.347 & 0.665 & 0.803 \\
\hline & & $\operatorname{Ln}(n)$ & 0.7 & 1.1 & 1.4 \\
\hline
\end{tabular}

$$
\mathrm{F}_{\mathrm{t}+1}=\alpha^{*} \mathrm{~A}_{\mathrm{t}}+(1-\alpha) * \mathrm{~F}_{\mathrm{t}},(7)
$$

Where $\alpha$ is smoothing coefficient, $\mathrm{A}_{\mathrm{t}}-$ actual value, $\mathrm{F}_{\mathrm{t}}-$ previous prognostication value, $\mathrm{F}_{\mathrm{t}+1}$ - next prognostication value. Minimal value of mean square deviations of model and actual indicators for experimental data in October 2015 is given in table 5 .

Table 5 data show that for prognostication of mistakes' quantity in sixth set (October 2015) coefficient $\alpha$ shall be chosen as equal to 0.9 (at minimal $\sigma$ ).

Thus it is possible to prognosticate the quantity of mistakes in October:

$$
\mathrm{F}_{6}=0.9 * 7.09+(1-9) * 6.421=7.023 \text {. }
$$

In the same way we can prognosticate for experimental group May data and control group data in October and
May (see tables 6, 7, 8).

So, prognosis of mistakes' quantity for sixth set of experimental group in May is:

$$
\mathrm{F}_{6}=0.8 * 5.19+(1-0.8) * 4.9772=5.1474
$$

So, prognosis of mistakes' quantity for sixth set of control group in October is:

$$
\mathrm{F}_{6}=0.9 * 7.15+(1-0.9) * 6.3495=7.0699 \text {. (8). }
$$

Prognosis of mistakes' quantity for sixth set of control group in May is:

$$
\mathrm{F}_{6}=0.9 * 5.79+(1-0.9) * 5.3485=5.7459 .
$$

Mean relative error $(\varepsilon)$, percentage of all predicted values does not exceed $10 \%$ : 
Table 5. Mean square deviations of model and actual indicators in experimental group in October 2015.

\begin{tabular}{|c|c|c|c|c|c|c|c|c|c|c|}
\hline$t$ & $A_{t}$ & $\begin{array}{l}F_{t+1} \\
\alpha=0.1\end{array}$ & $\begin{array}{l}F_{t+1} \\
\alpha=0.2\end{array}$ & $\begin{array}{l}F_{t+1} \\
\alpha=0.3\end{array}$ & $\begin{array}{l}F_{t+1} \\
\alpha=0.4\end{array}$ & $\begin{array}{l}F_{t+1} \\
\alpha=0.5\end{array}$ & $\begin{array}{l}F_{t+1} \\
\alpha=0.6\end{array}$ & $\begin{array}{l}F_{t+1} \\
\alpha=0.7\end{array}$ & $\begin{array}{l}F_{t+1} \\
\alpha=0.8\end{array}$ & $\begin{array}{l}F_{t+1} \\
\alpha=0.9\end{array}$ \\
\hline 1 & 4.24 & 5.74 & 5.74 & 5.74 & 5.74 & 5.74 & 5.74 & 5.74 & 5.74 & 5.74 \\
\hline 2 & 5.00 & 5.59 & 5.44 & 5.29 & 5.14 & 4.99 & 4.84 & 4.69 & 4.54 & 4.39 \\
\hline 3 & 5.90 & 5.31 & 5.352 & 5.203 & 5.084 & 4.995 & 4.936 & 4.907 & 4.908 & 4.939 \\
\hline 4 & 6.49 & 5.568 & 5.4616 & 5.4121 & 5.41 & 5.448 & 5.514 & 5.602 & 5.702 & 5.804 \\
\hline 5 & 7.09 & 5.66 & 5.66728 & 5.73547 & 5.842 & 5.969 & 6.1 & 6.224 & 6.332 & 6.421 \\
\hline & $\begin{array}{l}\text { are devia- } \\
\text { I and actual }\end{array}$ & 0.86 & 0.80 & 0.72 & 0.62 & 0.51 & 0.41 & 0.31 & 0.22 & 0.16 \\
\hline
\end{tabular}

Table 6. Mean square deviations of model and actual indicators in experimental group in May 2016.

\begin{tabular}{|c|c|c|c|c|c|c|c|c|c|c|}
\hline $\mathbf{t}$ & $A_{t}$ & $\begin{array}{l}F_{t+1} \\
\alpha=0.1\end{array}$ & $\begin{array}{l}\mathrm{Ft}+1 \\
\alpha=0.2\end{array}$ & $\begin{array}{l}F t+1 \\
\alpha=0.3\end{array}$ & $\begin{array}{l}\mathrm{Ft}+1 \\
\alpha=0.4\end{array}$ & $\begin{array}{l}\mathrm{Ft}+1 \\
\alpha=0.5\end{array}$ & $\begin{array}{l}\mathrm{Ft}+1 \\
\alpha=0.6\end{array}$ & $\begin{array}{l}\mathrm{Ft}+1 \\
\alpha=0.7\end{array}$ & $\begin{array}{l}\mathrm{Ft}+1 \\
\alpha=0.8\end{array}$ & $\begin{array}{l}\mathrm{Ft}+1 \\
\alpha=0.9\end{array}$ \\
\hline 1 & 4.02 & 4.7 & 4.7 & 4.7 & 4.7 & 4.7 & 4.7 & 4.7 & 4.7 & 4.7 \\
\hline 2 & 4.45 & 4.632 & 4.564 & 4.496 & 4.428 & 4.36 & 4.292 & 4.224 & 4.156 & 4.088 \\
\hline 3 & 4.81 & 4.6138 & 4.5412 & 4.822 & 4.4368 & 4.405 & 4.3868 & 4.3822 & 4.3912 & 4.4138 \\
\hline 4 & 5.04 & 4.6334 & 4.59496 & 4.5805 & 4.5861 & 4.6075 & 4.6407 & 4.68166 & 4.7262 & 4.77038 \\
\hline 5 & 5.19 & 4.6741 & 4.68397 & 4.7184 & 4.7676 & 4.8238 & 4.8803 & 4.9325 & 4.9772 & 5.01304 \\
\hline \multicolumn{2}{|c|}{$\begin{array}{l}\sigma, \text { mean square } \\
\text { deviation of } \\
\text { model and actual } \\
\text { indicators }\end{array}$} & 0.31 & 0.28 & 0.24 & 0.20 & 0.16 & 0.12 & 0.09 & 0.08 & 0.10 \\
\hline
\end{tabular}

Table7. Mean square deviations of model and actual indicators in control group in October 2015 .

\begin{tabular}{|c|c|c|c|c|c|c|c|c|c|c|}
\hline $\mathbf{t}$ & $A_{t}$ & $\begin{array}{l}F_{t+1} \\
\alpha=0.1\end{array}$ & $\begin{array}{l}\mathrm{Ft}+1 \\
\alpha=0.2\end{array}$ & $\begin{array}{l}\mathrm{Ft}+1 \\
\alpha=0.3\end{array}$ & $\begin{array}{l}\mathrm{Ft}+1 \\
\alpha=0.4\end{array}$ & $\begin{array}{l}\mathrm{Ft}+1 \\
\alpha=0.5\end{array}$ & $\begin{array}{l}\mathrm{Ft}+1 \\
\alpha=0.6\end{array}$ & $\begin{array}{l}\mathrm{Ft}+1 \\
\alpha=0.7\end{array}$ & $\begin{array}{l}\mathrm{Ft}+1 \\
\alpha=0.8\end{array}$ & $\begin{array}{l}\mathrm{Ft}+1 \\
\alpha=0.9\end{array}$ \\
\hline 1 & 4.25 & 5.74 & 5.74 & 5.74 & 5.74 & 5.74 & 5.74 & 5.74 & 5.74 & 5.74 \\
\hline 2 & 5.11 & 5.591 & 5.442 & 5.293 & 5.144 & 4.995 & 4.846 & 4.697 & 4.548 & 4.399 \\
\hline 3 & 5.79 & 5.5429 & 5.376 & 5.238 & 5.1304 & 5.0525 & 5.0044 & 4.986 & 4.998 & 5.0389 \\
\hline 4 & 6.42 & 5.5676 & 5.458 & 5.404 & 5.3942 & 5.4213 & 5.4758 & 5.549 & 5.632 & 5.7149 \\
\hline 5 & 7.15 & 5.6528 & 5.651 & 5.709 & 5.8045 & 5.9206 & 6.0423 & 6.159 & 6.262 & 6.3495 \\
\hline & $\begin{array}{l}\text { are devia } \\
\text { d actual }\end{array}$ & 0.84 & 0.78 & 0.70 & 0.59 & 0.48 & 0.37 & 0.25 & 0.14 & 0.04 \\
\hline
\end{tabular}

Table 8. Mean square deviations of model and actual indicators in control group in May 2016.

\begin{tabular}{|c|c|c|c|c|c|c|c|c|c|c|}
\hline $\mathbf{t}$ & $A_{t}$ & $\begin{array}{l}F_{t+1} \\
\alpha=0.1\end{array}$ & $\begin{array}{l}\mathrm{Ft}+1 \\
\alpha=0.2\end{array}$ & $\begin{array}{l}\mathrm{Ft}+1 \\
\alpha=0.3\end{array}$ & $\begin{array}{l}\mathrm{Ft}+1 \\
\alpha=0.4\end{array}$ & $\begin{array}{l}\mathrm{Ft}+1 \\
\alpha=0.5\end{array}$ & $\begin{array}{l}\mathrm{Ft}+1 \\
\alpha=0.6\end{array}$ & $\begin{array}{l}F t+1 \\
\alpha=0.7\end{array}$ & $\begin{array}{l}\mathrm{Ft}+1 \\
\alpha=0.8\end{array}$ & $\begin{array}{l}\mathrm{Ft}+1 \\
\alpha=0.9\end{array}$ \\
\hline 1 & 3.94 & 4.9 & 4.9 & 4.9 & 4.9 & 4.9 & 4.9 & 4.9 & 4.9 & 4.9 \\
\hline 2 & 4.43 & 4.804 & 4.708 & 4.612 & 4.516 & 4.42 & 4.324 & 4.228 & 4.132 & 4.036 \\
\hline 3 & 4.94 & 4.767 & 4.6524 & 4.5574 & 4.4816 & 4.425 & 4.3876 & 4.3694 & 4.3704 & 4.3906 \\
\hline 4 & 5.40 & 4.784 & 4.7099 & 4.6722 & 4.665 & 4.6825 & 4.719 & 4.7688 & 4.8261 & 4.8851 \\
\hline 5 & 5.79 & 4.846 & 4.8479 & 4.8905 & 4.959 & 5.0413 & 5.1276 & 5.2106 & 5.2852 & 5.3485 \\
\hline \multicolumn{2}{|c|}{$\begin{array}{l}\sigma, \text { mean square de- } \\
\text { viation of model and } \\
\text { actual indicators }\end{array}$} & 0.57 & 0.53 & 0.48 & 0.41 & 0.34 & 0.27 & 0.20 & 0.13 & 0.07 \\
\hline
\end{tabular}




$$
\varepsilon=\frac{1}{n_{i}=1} \sum_{i}^{n} \frac{\left|A_{i}-F_{i}\right|}{A_{i}} * 100
$$

Where $n$ is quantity of sets, $A_{i}$-actual values, $F_{i}-$ predicted values.

The data of experimental group comparative analysis (October 2015 and May 2016) are shown in fig. 1.

As we can see experimental group data are rather better at the end of experiment: in first set - by 0.22 ; in second set - by 0.55 and in the third set - by 1.09 ; in the forth set - by 1.02 and the fifth - by 1.9. Prognosis for sixth set in October was 7.023, and for May - 5.1474. Here we also see improvement by 1.8756 .

Comparative analysis of control group data for October and May is given in fig. 2.

As we can see the data of control group also improved by the end of experiment: in the first set - by $0.31 \%$; in the second - by $0.68 \%$; in the third - by $0.85 \%$; in the forth by $1.02 \%$ and in the fifth - by $1.36 \%$. Prognosis for sixth set in October was 7.0699, and for May - 5.74595. Here we also see improvement by 1.324 .

Comparative analysis of experimental and control

Quantity of made

mistakes

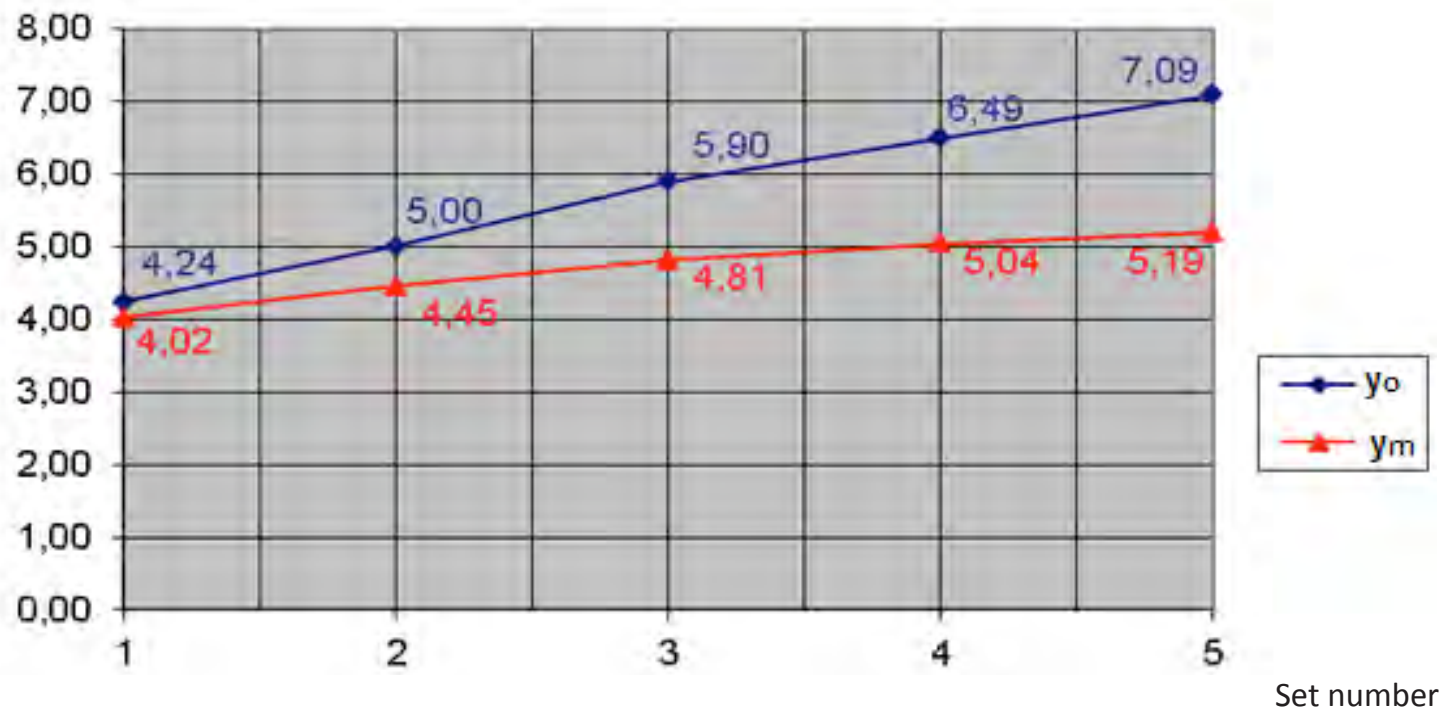

Fig. 1. Comparative analysis of experimental group data of October and May ping pong sets, where $y_{0}$-data for October and $y_{m}$ - data for May; $1-5$ numbers of sets; $0-8.00$ - quantity of made mistakes.

Quantity of made

mistakes

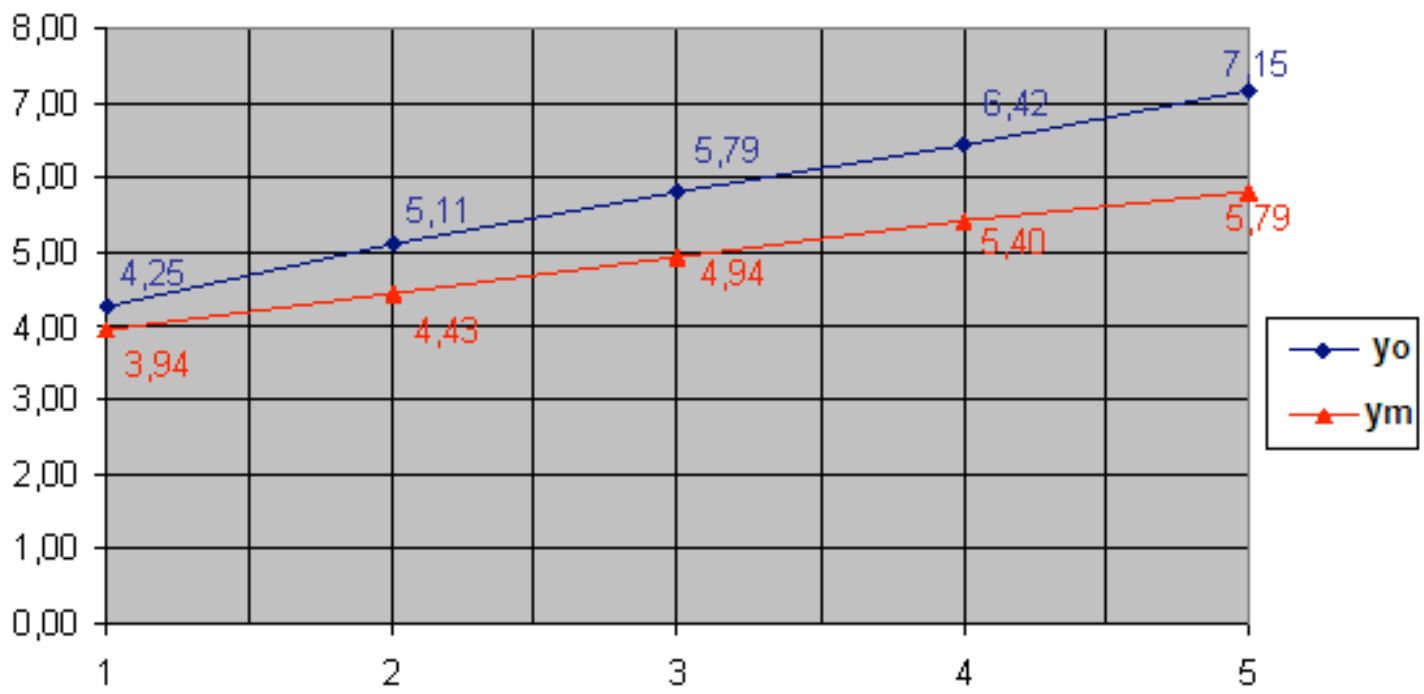

Set number

Fig. 2. Comparative analysis of control group data of October and May ping pong sets, where $y_{0}$-data for October and $\mathrm{y}_{\mathrm{m}}$ - data for May; $1-5$ numbers of sets; $0-8.00$ - quantity of made mistakes. 
groups data for October is shown in fig. 3 .

As we see the quantity of mad mistakes at the beginning of experiment (October) is nearly equal: in the first set, in experimental group the quantity of mistakes is less by 0.01 ; in the second - by 0.11 ; in the third set the quantity of mistakes was higher by 0.11 ; in the forth set - by 0.07 ; in the fifth set it was less by 0.06 . In predicted sixth set it was less by 0.0469 .

Comparative analysis of experimental and control groups data for May is shown in fig. 4.

At the end of experiment (May) the quantity of made mistakes in first two sets was nearly equal: in the first set in experimental group it was higher by 0.08 ; in the second set - by 0.02 . Starting from third set experimental group results are rather different from control group: in the third set quantity of made mistakes was less by 0.13 ; in the forth set - less by 0.36 ; in the fifth - by 0.60 . In predicted sixth set it was less by 0.5985 .

\section{Discussion}

For the first time: we proved effectiveness of methodological approach to working out of students' physical education programs for sport oriented groups, which combines commonly accepted means of physical qualities' training with special endurance trainings methods; we substantiated physical education program for students of sport oriented groups (sport circles trainings, ping pong), combined with aerobic exercises

Quantity of made
mistakes

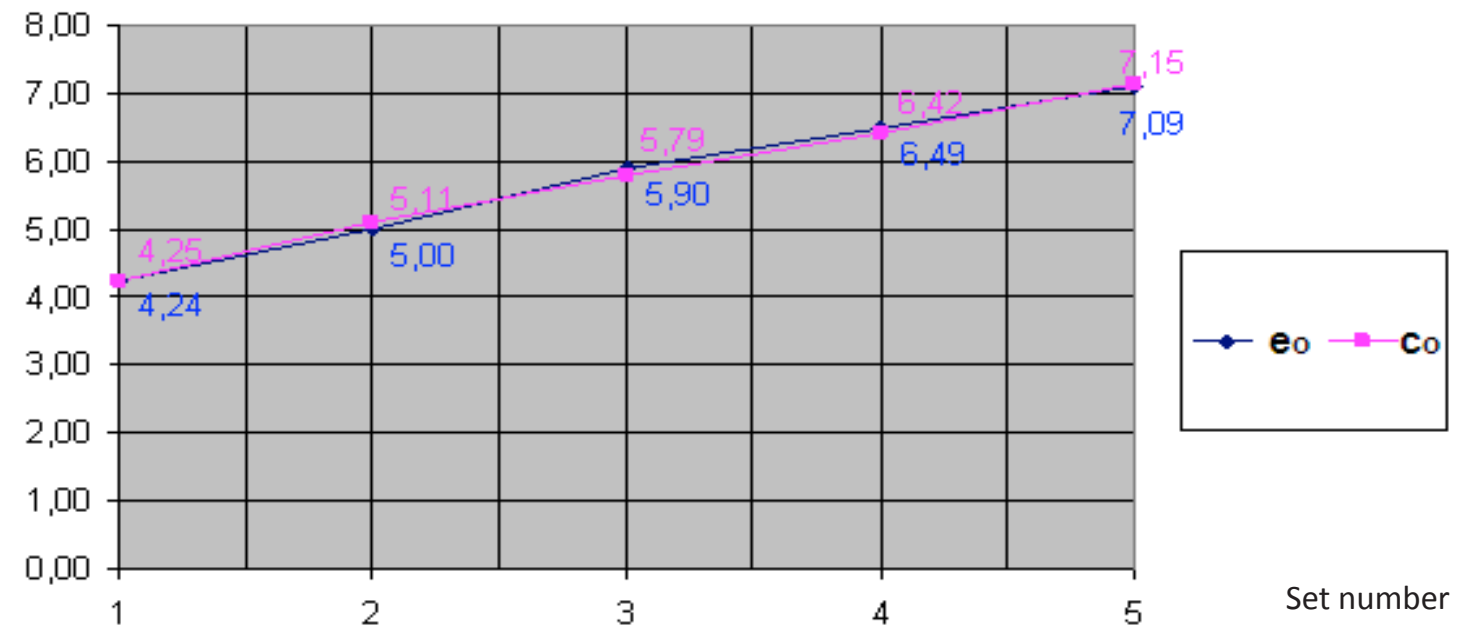

Fig. 3. Comparative analysis of experimental and control groups ping pong data for October, where $e_{o}-$ experimental group data for October, $c_{o}$-control group data for October, 1 - 5 set numbers, $0-8.00$ - quantity of made mistakes.

Quantity of made

mistakes

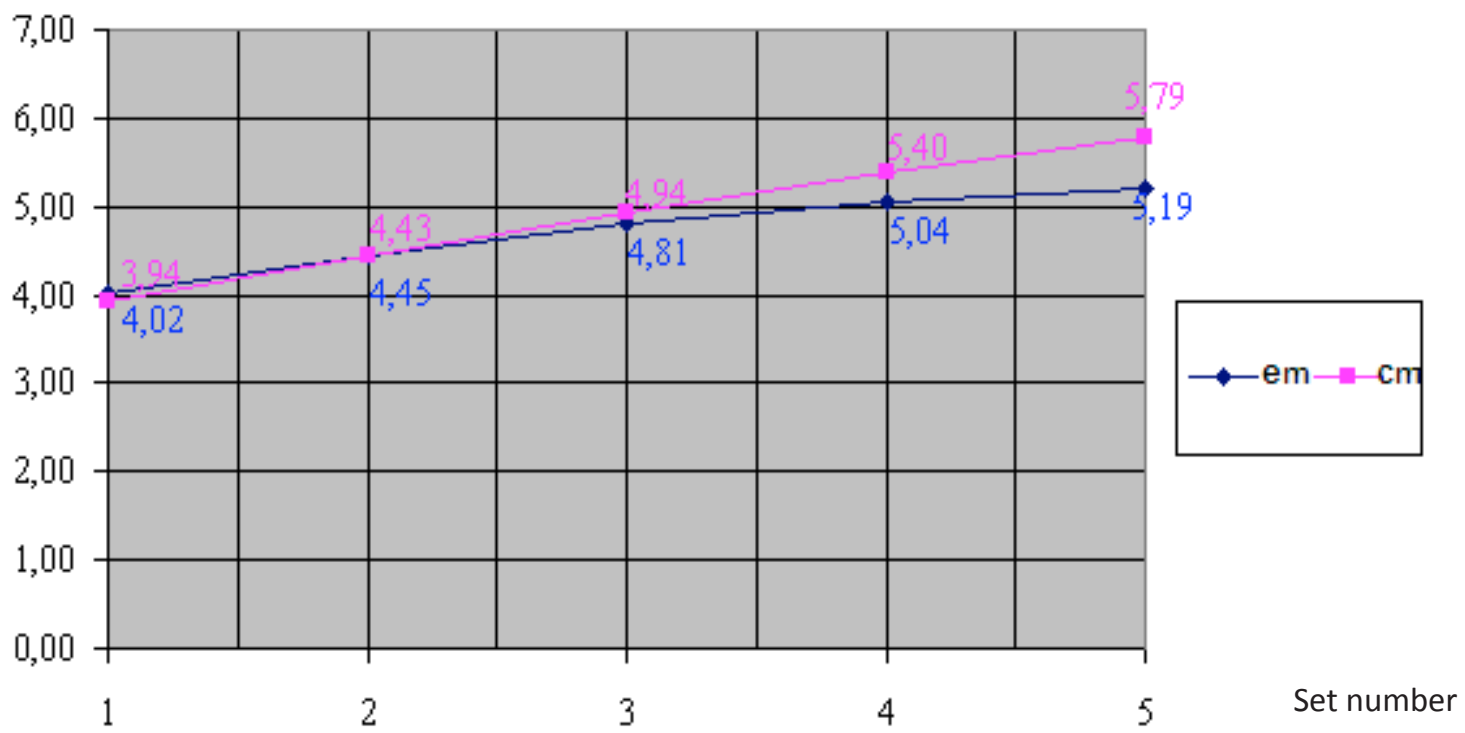

Fig. 4. Comparative analysis of experimental and control groups ping pong data for May, where $e_{o}-$ experimental group data for May, $c_{o}$-control group data for May, 1 - 5 set numbers, 0 - 7.00 - quantity of made mistakes. 
(cross country training, basic aerobic).

This program showed that experimental group students improved their general endurance. Though, they can lag behind in technical tactic training (sportsmanship). It is connected with the fact that every forth training contained aerobic loads (cross country, basic aerobic) instead of ping pong practicing. After experiment data of the fulfilled analysis witness that the chosen strategy was correct: experimental group special endurance results highly differ from those of control group (see fig. 4). Experimental group students made less quantity of mistakes; they became more attentive, concentrated and responsible in important moments of game. Our results point that aerobic loads in physical culture lessons did not influence negatively on students' technical-tactic fitness (see fig. 1). It should be noted that at the end of experiment control group results were better in first two sets (see fig. 4) than experimental group results. It is connected with better technical tactic fitness in control group: they had more special fitness trainings. However, from the third set (in spite of less quantity of technical-tactic trainings) experimental group students demonstrate better results (see fig. 4). It results from their better special endurance.

The received results supplement the data about influence of aerobic exercises on special endurance [5,
9]. It means that with correct correlation of trainings by physical education program for students' sport oriented groups (sport circles trainings) and at the cost of aerobic loads (cross country training and basic aerobic) it is possible to significantly improve students' special endurance.

\section{Acknowledgements}

The present work is a component of topical scientificresearch works' plan of Kharkov state academy of physical culture "Influence of aerobic trainings on general and special endurance in sport oriented groups”.

\section{Conclusions}

It was proved that introduction of aerobic trainings (cross country race and basic aerobic elements) in training program for sport oriented groups (sport circles trainings, ping pong) positively influenced on students' special endurance. It was shown that method of exponential smoothing permits to prognosticate one set ahead with rather high accuracy.

\section{Conflict of interests}

The authors declare that there is no conflict of interests.

\section{References}

1. Mandelbrot B. The Behavior of Markets: A Fractal View of Financial Turbulence. Hardcover; 2004.

2. Peters E. Chaos and Order in the Capital Markets. New York: John Wiley; 1991.

3. Rendi M, Szabó A, Szabó T, Velenczei A, Kovács A. Acute psychological benefits of aerobic exercise: a field study into the effect of exercise characteristics. Psych Health Med., 2008;13(2):180-184

4. Sharon A Plowman, Denise L Smith. Exercise Physiology for Health Fitness and Performance. Lippincott Williams \& Wilkins; 2011.

5. Weerahandi S. Exact Statistical Methods for Data Analysis. Springer: NY: 1995.

6. Ajvazian SA, Mkhitarian VS. Prikladnaia statistika $i$ osnovy ekonometriki [Applied statistic and principles of econometrics], Moscow: IuNITI; 1998. (in Russian)

7. Afonasova MA. Upravlenie formirovaniem naukoemkikh integrirovannykh struktur $v$ inovacionno aktivnykh regionakh [Administrating of formation of scientifically capable structures in innovatively active regions]. Fundamental'nye issledovaniia, 2009;3:111 - 112. (in Russian)

8. Bikmukhametov RK. Soderzhanie processa fizicheskogo vospitaniia $\mathrm{V}$ sisteme pedagogicheskogo obrazovaniia [Physical education process in system of pedagogic education]. Teoriia $i$ praktika fizicheskoj kul'tury, 2003;3:45-50. (in Russian)

9. Grin'ko VM. Stavlennia studentiv do fizichnogo vikhovannia i zdorovogo sposobu zhittia ta ikh samoocinka rivnia fizichnoi pidgotovlenosti [Students' attitude to physical education and healthy life style; their self assessment of on physical fitness]. Slobozhans 'kij naukovo - sportivnij visnik, 2015;1(45):55-59. (in Ukrainian)

10.Grin'ko VM. Zaniattia aerobnogo kharakteru ta ikh mozhlivij vpliv na riven' zagal'noi ta special'noi vitrivalosti studentiv [Aerobic trainings and their possible influence on students' general and special endurance]. Naukovij chasopis NPU imeni M. P. Dragomanova, 2015;12(67):42-45. (in Ukrainian)

11.Dubnic'kij VIu. Vibir metodu prognozuvannia vartosti cinnikh paperiv z urakhuvanniam fraktal'noi vimirnosti riadu sposterezhen' [Choice of prognostication method for security papers' cost, considering fractal dimension span of observations' series]. Biznes, 2011;7 (1):120-121. (in Ukrainian)

12. Izaak SI. Fizicheskoe razvitie i fizicheskaia podgotovlennost' $\mathrm{v}$ sisteme monitoringa sostoianiia fizicheskogo zdorov'ia naseleniia [Physical condition and physical fitness in monitoring of population's physical health]. Teoriia $i$ praktika fizicheskoj kul 'tury, 2004;11:51-52. (in Russian)

13. Kartashov MV. Imovirnist', procesi, statistika [Probability, processes, statistic] Kyiv: Kyiv CUP University; 2007. (in Ukrainian)

14. Kudelko VE. Effektivnost' organizacionnoj deiatel'nosti v sisteme sportivnykh klubov [Effectiveness of organizational functioning in sport clubs' system] Fizicheskoe vospitanie studentov tvorcheskikh special'nostej, 2004;3:79-85. (in Russian)

15. Kudelko VE, Korolins'ka SV. Analiz social'nopedagogichnikh osnov formuvannia potreb $\mathrm{v}$ samostijnikh zaniattiakh fizichnoiu kul'turoiu u studentiv NFaU [Analysis of social-pedagogic principles of demands' formation for independent physical culture practicing by NFaU students]. Pedagogics, psychology, medical-biological problems of physical training and sports, 2006;12:93-96.

16. Kudelko VE, Shcherbina ZI, Pavlenko EE. Ocenka fizicheskogo sostoianiia $i$ fizicheskoj podgotovlennosti studentov [Students' physical condition and fitness]. Kharkov: National University of Pharmacy; 2003. (in Russian)

17. Lemeshko BU, Pomadin SS. Korreliacionnyj analiz nabliudenij mnogomernykh sluchajnykh velichin pri narushenii predpolozhenij o normal'nosti [Correlation 
analysis of observations over multi-dimensional occasional values with violation of assumptions about normality]. Sibirskij zhurnal industrial'noj matematiki, 2002;5(3):115-130. (in Russian)

18.Lykov IA, Okhotnikov SA. Vliianie izmeneniia funkcii Khersta na vozmozhnosti ekonomicheskogo prognozirovaniia [Influence of Hurst's function's change on possibilities of economic prognostication]. Fundamental'nye issledovaniia, 2013;10:1539 - 1544. (in Russian)

19.Mardia K, Zemroch P. Tablicy F-raspredelenij i raspredelenij, sviazannykh s nimi [Tables of F distributions and distributions connected with them]. Moscow: Science; 1984. (in Russian)

20.Novikova NB. Fraktal'nye metody i koncepciia ekonomicheski minimal'nykh proizvodstvennykh sistem v upravlenii innovaciiami [Fractal methods and conception of economically minimal production systems in monitoring innovations]. Vestnik IuRGTU, 2011;2:162-166. (in Russian)

21. Arziutov G, Iermakov S, Bartik P, Nosko M, Cynarski WJ. The use of didactic laws in the teaching of the physical elements involved in judo techniques. Ido Movement for Culture, 2016;16(4):21-30. doi:10.14589/ido.16.4.4

22.Bliznevsky AA, Kudryavtsev MD, Iermakov SS, Jagiello W. Formation of active-effective attitude of 12-13 years' judo athletes to sports functioning in competition period. Archives of Budo. 2016;12:101-15.

23.Iermakov SS, Arziutov GN, Jagiello W. Quick training of students to judo techniques. Archives of Budo. 2016;12:1524.

24.Iermakov SS, Podrigalo LV, Jagiello W. Hand-grip strength as an indicator for predicting the success in martial arts athletes. Archives of Budo. 2016;12:179-86.

25.Najman E. Raschet pokazatelia Khersta s cel'iu vyiavleniia trendovosti (persistentnosti) finansovykh rynkov i makroekonomicheskikh indikatorov [Calculation of Hurst's indicator for determination of trends (persistence) of financial markets and macro-economical indicators]. Ekonomist, 2009;10:25-29. (in Russian)

26. Chajkovs'ka II. Zastosuvannia suchasnikh informacijnikh tekhnologij dlia modeliuvannia ekonomichnikh procesiv na osnovi fraktal'nogo analizu [Application of modern innovative technologies for economic processes' simulation on the base of fractal analysis]. Universitets'ki naukovi zapiski, 2014;1:378-387. (in Ukrainian)

27.Chajkovs'ka II. Kompleksna model' upravlinnia intelektual'nim kapitalom pidpriiemstva [Complex modl of management of enterprise's intellectual capital]. Ekonomichnij chasopis, 2012;7-8:75-79.

28.Chajkovs'ka II. Ekonomiko-matematichne modeliuvannia $v$ upravlinni intelektual'nim kapitalom pidpriiemstva [Economical-mathematic modeling in management of enterprise's intellectual capital], Khmelnitsky, Khmelnytsky University of Management and Law; 2014. (in Ukrainian)

29.Chajkovs'ka I.I. Deiaki aspekti zastosuvannia fraktal'nogo analizu pri doslidzhenni ekonomichnikh procesiv [Some aspects of fractal analysis application in economical processes' studies]. Informacijne suspil'stvo: tekhnologichni, ekonomichni ta tekhnichni aspekti stanovlennia, 2014;1:10-11. (in Ukrainian)

Information about the authors:

Grinko V. M.; http://orcid.org/0000-0002-5118-9558; vngrinko78@mail.ru; Kharkiv State Academy of Physical Culture; Str. Klochkovskaya 99, Kharkiv, 61002, Ukraine.

Kudelko V. E.; http://orcid.org/0000-0001-9252-8563; vikikudelko@mail.ru; Kharkiv Institute of Finance Kyiv National Trade Economic University; Lane Pletnivskyy, Kharkiv, 61000, Ukraine.

Hlotov Y.O.; http://orcid.org/0000-0001-8724-7572; glotov50@mail.ru; Kharkiv Institute of Finance Kyiv National Trade - Economic University; Lane Pletnivskyy, Kharkiv, 61000, Ukraine.

Cite this article as: Grinko VM, Kudelko VE, Hlotov YO. Training of students' special endurance in ping pong sport circles. Physical education of students, 2017;2:52-60. doi:10.15561/20755279.2017.0201

The electronic version of this article is the complete one and can be found online at: http://www.sportpedagogy.org.ua/index.php/PPS/issue/archive

This is an Open Access article distributed under the terms of the Creative Commons Attribution License, which permits unrestricted use, distribution, and reproduction in any medium, provided the original work is properly cited (http://creativecommons.org/licenses/by/4.0/deed.en).

Received: 27.12 .2016

Accepted: 15.01.2017; Published: 04.04.2017 